\title{
Parents of Gay Sons Redefining Masculinity
}

\author{
Joanne Cassar, Marthese Grima Sultana \\ Department of Youth and Community Studies, Faculty for Social Wellbeing, University of Malta, Msida, Malta \\ Email: joanne.cassar@um.edu.mt
}

How to cite this paper: Cassar, J. and Grima Sultana, M. (2017) Parents of Gay Sons Redefining Masculinity. Open Journal of Social Sciences, 5, 170-182. https://doi.org/10.4236/jss.2017.58014

Received: July 3, 2017

Accepted: August 11, 2017

Published: August 14, 2017

Copyright () 2017 by authors and Scientific Research Publishing Inc. This work is licensed under the Creative Commons Attribution International License (CC BY 4.0).

http://creativecommons.org/licenses/by/4.0/ (c) (i) Open Access

\begin{abstract}
Becoming a man often signifies adherence to social dictates that expect men to be physically strong, self-reliant, resilient, tough and emotionally detached even if this is achieved at the expense of close and meaningful relationships. Dissatisfaction with this type of traditional masculinity has mounted pressure to reevaluate what defines masculinity in efforts to address gender equality and assert the diverse needs of men and women. Perceptions around the masculinity of gay persons and the discourses that associate homosexuality with a "weak" manhood are also being questioned. We present a study that examines perceptions that Maltese parents of gay sons hold on masculinity and how these might affect their relationship with each other. The inquiry focuses on whether coming out has affected the perceptions of parents of gay sons on masculinity, as described by them. We deem this research question important because parents' perceptions on masculinity might affect their relationship with their children. The findings that conveyed through qualitative interviews indicate that the embodiment of masculinity norms was accounted for in various family dynamics and relations and shaped how the parents reacted to their son's coming out and eventual acceptance of his sexuality. Although some aspects of traditional masculinity were held in place even after coming out, the parents were able to shift their perceptions to include a more comprehensive idea about what "being a man" means. This implies that conceptualizations on lived masculinities are moving away from social constructs that define it as unitary, stable and uncontested.
\end{abstract}

\section{Keywords}

Masculinity, Coming out, Homosexuality, Sexual Orientation, Parents

\section{Contested Masculinities}

The concept of masculinity brings together notions related to male identity, manhood, men's roles and manliness [1]. These impact on the manner which en 
relate, function and adapt. Masculinities are socially, culturally and historically constructed and reproduced through social forces, structures and standards surrounding behaviours and personal characteristics. Numerous discourses that comprise different types of masculinities co-exist and these often compete with one another [2], intersecting with factors such as age, sexual orientation, race and class. The making of masculinities is intricately connected to the body and to repeated performances that enact and produce it. Gender is "the repeated stylisation of the body, a set of repeated acts within a highly rigid regulatory frame that congeal over time to produce the appearance of substance, of a natural sort of being" [3]. Concepts of masculinity are not homogenous across cultures. Hegemonic masculinities are generally signalled through dominant and stereotyped notions surrounding physical appearance and strength, assertiveness and social status. They are also manifested through the perceived superiority of white, heterosexual men over women and over people pertaining to sexual and racial minorities. The association of homosexuality with "lack of manliness" [4] has historically rendered the masculinity of gay persons as "weak" and placed it within non-traditional masculinity. Legislative developments in gay rights and gender equality occurring alongside rapid changes in numerous societies have however called into question the usefulness of traditional masculinity. Women and men are increasingly disapproving of traditional masculinity [5]. Forms of masculinities that revolve around societal expectations to be physically strong, self-reliant and emotionally detached, leave less space for the formation of close and meaningful relationships [6]. Traditional ideals of masculinity have been associated with aggression, violent behaviours, low self-confidence and depression [6]. Adherence to non-traditional masculinity, ideology positively affects romantic relationships for both heterosexual and gay men [7] and increases the level of satisfaction of both males and females in heterosexual intimate relationships [8] [9]. Masculinity is increasingly being considered a fluid and even ambiguous concept. This has given way to discourses that place masculinity in a crisis characterized by men feeling bewildered and confused about their roles at home and in the workplace [10]. While a number of studies have examined the effects which views on masculinity have on heterosexual dating and marital relationships, there have been fewer studies that examined the perceptions that parents of gay children hold on masculinity and how these might mediate their relationship with them. We present a qualitative study on the notion of masculinities as perceived by a number of Maltese parents who have a gay son. The study examines whether coming out has affected the perceptions of parents of gay sons on masculinity, as described by them. We deem this research question important because parents' perceptions on masculinity might affect their relationship with their children.

The study is situated in contradictory social contexts. There are some aspects of Maltese society that keep homosexuality in a cultural and social closet which shrouds it in secrecies [11] [12]. Although communities in Malta are closely knit and enable easier access to social solidarity "taboos surrounding homosexuality 
are easily reproduced and amplified" [13]. On the other hand, Malta is now considered to be one of the most progressive countries with regards to lesbian, gay, bisexual, transgender, queer and intersex (LGBTQI) rights, since it became the first European country to criminalize "deceptive and harmful" conversion therapy, aimed at any practice which attempts to change, repress, discredit or eliminate a person's sexual orientation or gender identity [14]. In 2014, The Civil Unions Act granted the legal right to persons of the same sex to register their partnership as a civil union; these rights being the same as those of a civil marriage, including the adoption of children [15]. In 2015 Malta shot up to the top rank among 49 European countries with regards to legislation and policies that impact positively on the lives of LGBTQI persons [16]. This progress was "buoyed by an irresistible combination of determined activism and unprecedented political leadership at national level, which led to the adoption of ground-breaking legislation and comprehensive public policies" [16]. At the time of writing this article Malta became the 25th country in the world and the 15th in Europe to legalise marriage equality. The Marriage Equality Act recognizes that any person irrespective of gender identity and sexual orientation is free to contract marriage and to parent children. This law stipulates that the institution of marriage is gender neutral and ensures that unnecessary references to parents' gender or sexual orientation are not included in their children's birth certificates [17]. These legislative changes are bound to have considerable effects on the lives of LGBTQI persons. Shifts in perspective are also evident as 77\% of Maltese citizens claim that GLB persons should be granted the same rights as heterosexual persons [18]. Progress in legislative frameworks and policies however do not always translate into changes in mentality and lifestyles straightaway. The transition is marked by socially prescribed behaviors that regulate how masculinity should be expressed and how the social scripting of homosexuality is affected [13]. A body of research documents the strong links between heterosexual privilege and hegemonic masculinities and how these produce homophobia (e.g. [19] [20]). Gender scripts that ascribe toughness, aggression and competition to males prescribe values that could lead to discrimination and violence. Harrowing and horrific stories of Maltese young gay men show that brutal physical aggression and abuse were used to coerce them into "manhood", as the following narratives demonstrate:

My father has often, since I was a child, beaten me up to make me become a man. Once he held me against the wall and chocked me. This violence goes on to this day. When I was 13, my uncle raped me. I told my mother but she said, "We cannot do anything because it's your uncle and he would end up in prison." When I tried to report the violence, my father ran after me, pushed me down the stairs and broke my nose (Gay person aged 18 - 25).

I was kissing a man in a public place and my father, without me knowing, was standing on the opposite side of the street. He approached me and started swearing. He hit me, then punched me and then kicked me. I didn't report this to the police because it's my father and I thought it was a natural 
reaction for a homophobic but loving father (Gay person aged under 18). My brother once pushed me down the stairs and I broke one of my teeth. The reason given for this was for me to become a man. On another occasion, he pulled my hair because he thought I was acting too effeminate. At school, there was once a student who first started insulting me and then wanted to test my strength and see how manly I was. He pushed me and I fell to the ground. He sat on me and slapped me twice in the face. I didn't report any of the above incidents to the police because my mother didn't want me to (Bisexual person aged 18 - 25) [21].

Adolescent boys are brought up around expectations to habitually hide their emotions underneath tough guises [6]. Family dynamics are not considered neutral sites in terms of values associated with sexual minority rights. Family lives reflect cultural and political arenas that play out different value systems that often struggle with each other. Masculine identities are shaped by social affiliation and kinship networks with others. The realization that a son is gay might lead fathers to question their own masculinity and contributes to a diminished sense of manliness [4]. Parents might blame themselves for their children's homosexual orientation. Some research shows that fathers feel that their masculine identity is threatened and expressed guilt for not transmitting a strong sense of masculinity to their gay son by for example not being good at sports and not spending enough time with him when he was growing up. Mothers attributed their children's homosexual orientation to the shortcomings in their marriage and to giving wrong messages to their children [22].

\section{The Study}

\section{Data Collection}

The data (Table 1) on which the inquiry is based were derived from a set of semi structured interviews with four married Maltese heterosexual parents of young gay men, who came out to their parents when they were $16-20$ years old. Parents' ages ranged between 45 and 63 years and they were interviewed separately, not as a dyad. Their sons' ages were 20 and 31 at the time of the data collection. Interviewees were recruited through two gay persons who distributed our invitation for research participation to parents they knew. Our invitation was open to parents of children who identified themselves as LGBTQI. Although originally we wanted to include parents of children with a variety of non-normative sexual orientations only parents of gay sons responded. We selected the first 4 couples who contacted us. They all have one male child, whom they described as gay. We acknowledge that a contradictory relationship between sexual identity and sexual behaviour sometimes arises and therefore we do not exclude the possibility that the children of the informants were bisexual or otherwise. We define the research sample as being comprised of "parents of gay sons" because this is how the informants described themselves. The interviews were conducted by author 2 in November 2013. 
Table 1. List of informants.

\begin{tabular}{ccc}
\hline Parent's name & Parent's age & Marital couple 1 \\
\hline Tina & 62 & \\
Sam & 63 & Marital couple 2 \\
Anthony & 60 & \\
Angela & 58 & Marital couple 3 \\
Lucy & 45 & \\
Paul & 48 & Marital couple 4 \\
Sonia & 49 & \\
Joseph & 51 & \\
\hline
\end{tabular}

Nearly all the participants pertained to English-speaking backgrounds and their interview was conducted mainly in English with some sentences, phrases, expressions or words in Maltese. Three participants (Angela, Lucy and Paul) preferred to speak in Maltese throughout their interview. Direct quotations from their interview presented in this article have been translated into English. Each participant was interviewed once for an average of one and a half hours. A set of pre-planned questions were used to guide the interview. These were related to how parents conceptualized masculinity in general before their son came out and whether their perceptions on masculinity had changed as a result of the discovery that their son was gay. Interviews were transcribed and coded according to the method established by Braun and Clarke [23], in order to identify patterns and themes to be reported and analyzed within the data [23]. We employed this method to derive key meanings and concepts on masculinities as seen through the lens of the parents and mediated through their understandings of their relationship with their son. Specifically, meanings derived from the informants' narrated experiences and perspectives were grouped according to 1) perceptions of masculinity before coming out and 2) how these affected their relationship with their son after this event.

Ethical clearance from the University of Malta's research ethics committee was obtained. Consent was also requested and obtained from the informants' sons in order to ensure third party confidentiality. Names of the research informants and other identifying details have been changed to safeguard anonymity. We were aware of the sensitive nature of the topic and of the possibility that the informants might feel uneasy to talk about certain experiences surrounding coming out. It was therefore pertinent to establish a certain degree of trust with the parents and be ethically sensitive towards them when conducting interviews. Author 2 noticed that the mothers seemed to be much more eager than the fathers to recall and recount their personal narratives of their son's coming out and provided more detailed information. Many of them seemed to have found the interview "therapeutic" because "talking made them feel better" and claiming that usually they "didn't have anyone to talk to about it". Two parents said that their interview had been the first occasion that arose to talk to someone other 
than their spouse about their child being gay. All the mothers interviewed claimed to feel "lighter" after the interview. Once the audio-recorder was switched off they prolonged the "chat" and expressed their thanks for being given the opportunity to talk about their situation with someone else outside their family.

\section{Findings}

Before their son's coming out the parents in general perceived masculinity in a traditional sense and held expectations for their sons that revolved around domineering positions in terms of social standing. Conventional gender roles were passed on to their children: "For example, when they were young I wouldn't think about it but if I saw them playing with dolls I would take it away. I had nothing against them (homosexual individuals) but I didn't want it (homosexuality) on my sons" (Lucy). Although Lucy insisted that gay and lesbian persons are "normal" and that she never held any grudges against them she was always afraid that one of her sons would be gay. Sonia had noticed that her son lacked "machismo" whilst growing up, but did not equate it with homosexuality:

Yes, a bit, but many years ago, when he was maybe 4 or 6 , very young. I had commented in fact, I had commented, from the way he was into doing things too much proper, very self-conscious of what he wears. He wasn't the typical sort of rough boy, very sensitive, extremely caring and warm and affectionate (Sonia).

Anthony, Sam, Paul and Tina claimed to be very surprised to learn that their child was gay, since their son was "macho". Tina was even concerned that her son was too much of a ladies' man and that all the attention he was getting from girls was going to distract him from his studies. Prior to their son's coming out none of the parents had given much thought about homosexuality: "Because erm, I always thought about it as something that happened to other people and not to you" (Tina). When homosexuality was mentioned it was usually framed within discourses that made fun of it. Sam used to recount gay jokes imbued with heterosexist language in front of his son when he was unaware that his son was gay. Eventually, the first thing he did when he got to know was to apologize profusely to his son about his jokes and for speaking badly about gay persons. Before coming out the informants' sons knew that homosexuality was considered taboo by their family members and expected heart wrenching reactions. Nearly all the parents reported that the time prior to their child's coming out was marked by a considerable degree of anxiety for their sons, who were described as "fidgety, moody, nervous" and "keeping to himself". Sonia and Lucy suspected that something was wrong and were worried it could be something serious like ill health or trouble at work. Sonia noticed her son was making frequent use of mild painkillers and also of tissue paper and assumed it was because he was spending considerable time crying. Lucy's son retrieved to his own world 
and spent all day at his computer while he "had a lot of blues, snapping at us all the time". All the parents said that their son wanted them to know about their sexual orientation. In all cases, the mother got to know first and she was asked to pass the news to her husband. Some of the parents were greatly overwhelmed when the disclosure was made. Lucy nearly fainted and for months kept hoping that her son would not "remain gay". Joseph's initial reaction was to seek professional advice from a priest or psychologist, as he felt he needed support to come to terms with this reality. According to Paul having the guts to face one's parents was a sign of manhood and he admired his son for this: "For me he was a real man for not lying to us. I would take it more personally if he had to lie to me. If you are a liar, I cannot trust you. Since he told us, he was a mature man and I respect him". Sonia shared the same experience of feeling relieved that her son chose to disclose the news directly to her. The parents made less emphasis on their admiration for their son for not lying to himself by denying his sexual orientation, as in the case of persons who struggle with internalized homophobia. Coming out was generally described as an emotional ordeal for both sons and parents, but the latter reported that the situation got calmer after some time. The parents' main concern was the wellbeing, safety and happiness of their son and they were extremely protective of them. Before Sonia disclosed the news to her husband she had already decided that she would be on her son's side at all costs and love him unconditionally, even if her husband were to disagree with her:

I would stand by my son no matter what. So I woke up very confident. When I told my husband it was already quite clear what my position was and I was like ready to defend it as well. That was a very trying moment (Sonia).

Anthony explained how the disclosure of their child's sexual orientation was not shared with other family members so as to "avoid trouble" and keep them wondering whether their son was gay or not. Even with their extended family members and neighbours he and his wife did not feel at ease bringing up the subject, because they were afraid that they would be subjected to gossip, cruel judgments, ostracism and ridicule. Anthony was apprehensive about his son being made the object of some form of collective amusement by his extended family. He described the topic of homosexuality as the "elephant in the room" and a "ticking bomb about to explode at any time", which was being purposely ignored. At the time of the interview Anthony's parents still found it difficult to talk about the issue even with their other son and brother-in-law:

There are a lot of family members that suspect and we don't discuss it. And it seems to work but we are putting it under the carpet as much as we can, then someday it will explode. Especially with his brother, since we never discussed it ... Once we spoke very briefly about it me and my brother-in-law, because his daughter knows but we did not delve into it and I think because he felt it was embarrassing but we did not go into the subject 
(Anthony).

Tina reported that she felt at ease talking about her son's homosexuality with young people she knew and spoke openly with them. With regards to adults she was cautious about what to say and if the subject didn't crop up, she wouldn't bring it up. In general the parents were worried that their son's outward "effeminate" behaviour, appearance and the label of being gay might lead them to face adversities, humiliation, ridicule and discrimination throughout life. Their main concern was that their son would not socially fit within the stereotyped notions of masculinity and consequently be bullied and made to suffer dire consequences including stigmatization. They were also afraid that their son would base his self-worth on social standards that dictated how masculinity should be lived out and consequently suffer from low self-esteem. Angela was concerned that her son would not measure up to people's expectations with regards to social standards and demands placed on men. She feared that people would define her son strictly by his sexual orientation and not by his overall capabilities as a medical doctor: “I didn't want people who have certain prejudices about certain sexualities to look at him in a different light, as a man that likes other man, and not as the bright, intelligent doctor that he is". Nearly all the fathers associated homosexuality with effeminacy and hinted that they would feel uneasy if they were to witness their son kissing his partner. They were against public demonstrations of their physical affection and preferred that their son did not "look" gay and neither be conspicuous. They hinted that as much as possible "homosexual tendencies" should be hidden and rendered invisible and not even talked about in certain circumstances. Paul emphasized that gay men who flirt with straight men are annoying, adding that "even those that are obvious bother me, they should live their life". Anthony explained that even after the coming out of his son, he did not regard sexual acts between men as morally acceptable and denied the idea that men could possibly refrain from being sexually attracted to women. He discounted the idea of "a complete gay man" and believed that all gay men are attracted to men and women. He insisted that having sexual feelings for women was an essential part of being a man, irrespective of sexual orientation. He described same sex relationships as "fruitless". Tina explained that sometimes she sees her son looking at other girls and women "in a way a straight man would, in a rather too detailed way." Despite claiming to respect her son's long term partner and their relationship she still believed that her son was "pushed into becoming gay" by his peers, whom at the time of his coming out were gay. Bisexuality was never mentioned by the parents of the study.

Despite their initial reaction, the parents were aware of their advantage and personal capabilities in being able to handle coming out in a relatively calm way and in being able to shape their own conceptualisations of masculinities in ways that did not put their positive relationship with their son in jeopardy. While the fathers seemed to accommodate norms that placed restrictions on the public manifestation of affection between men by silencing themselves, their wives 
seemed to be more willing to speak out. Angela, Tina and Sonia were faced with disapprovals from people they knew, but these encounters made them even more determined to root for their son. Anthony explained that the journey into accepting his son as a gay person was still in its early stages. He insisted that his son's happiness and wellbeing came first and he wanted to establish a good relationship with him. Yet he envisaged obstacles like for example if his son were to bring home a partner. He stated that he didn't know how he would react. He also admitted fearing "the new social circles he (his son) would be exposed to". On the other hand, Anthony was not against gay marriage and adoption by gay couples, claiming that their marriage or civil union should be treated as "something sociological and not religious" and that "if it won't work it will be dropped". Most of the parents had no doubt that their sons would have their full support if they ever decided to adopt a child. They acknowledged their desire and capacity to form a family. Tina made it clear that raising a child in a good way depended on the love and education the parents give the child and not on their gender:

In my career as a teacher I've come across hundreds of "normal" as they call them, families who have not been able to bring up their children. I'm sure that if my son, knowing my son, if he had to bring up a child, he would certainly be brought up in a very exemplary way (Tina).

The mothers in particular highlighted the positive attributes of their son's character and personality. Angela remarked about her son's "wonderful character" and "kind heartedness". Sonia was also convinced that her son "is perfectly normal, perfectly confident, very able to love, very able to succeed in his future because he has a lot of gifts and talents". The data indicate that the mothers described their affection towards their gay son in a more pronounced way than the fathers. They articulated feelings of love for them in clear terms. The fathers did not use this terminology, but implied their love when talking about care, pride and respect towards their son. All the parents claimed that their relationship with their gay son grew stronger after their child's coming out and that their son appeared to be much calmer, happier and closer to them. The parents showed that they were not only protective of their son but also of their close bond as a family: "We've always lived as a family. And we always walked together" (Paul).

\section{Discussion}

The study confirms other findings that show parental acceptance of a child's homosexual orientation is multi-levelled and entails a process of exploration and adjustment [22]. The findings indicate that parents had internalized a heteronormative framework in the telling of their sons' coming out stories through a dominant coming out narrative that speaks of being initially surprised by the news that their child is gay, declaring confusion over what homosexuality means, seeking knowledge and support and finally admitting they are proud 
parents [24]. The informants were at different stages of their child's acceptance and in their understanding of the implications which their held notions of masculinity were having on their relationship with their child. In principle, they all agreed that they have accepted their son's homosexuality, but the fathers laid out clearly what they could not accept, such as gestures that manifested gayness publicly and which they felt compromised normative forms of masculinity. Anthony and Paul especially seemed to protect the image of traditional manhood by wanting their son to refrain from constructing themselves as identifiable homosexual subjects. The focus on regulating their son's public behaviour and gestures which they thought were incongruent with masculine norms stemmed more from their concern for their son's safety than from an outright rejection of the embodiment of their son's masculinity. They reinforced conventional masculine privileges as a response to "social difficulties not encountered by heterosexual youth" [25]. Stigma and prejudice are more associated with sexual minority youth than with heterosexual individuals [26]. We argue that this could be defined as a defensive approach towards hetero-male power over gay persons. Yet we acknowledge that mitigation against homophobic forces is daunting and could increase parents' personal anxieties. Consequently, parents could find it easier to uphold normative masculinity in varying degrees than go against cultural flows that affirm it. Homophobia therefore plays a role in the constitution of masculinities. Our data indicate that the mothers have shown a less defensive approach than their husbands when confronted with criticism about homosexuality and its moral standing. They implied that despite social pressures to conform to public masculine norms, lived masculinities are negotiable.

With their son's coming out, the parents were faced with the question "What does it mean to be a man?" Their desire and capacity to form close and meaningful relationships with their son have led them to question traditional forms of masculinity entrenched within heterosexual paradigms in order to adapt to their situation. When defining masculinity, the informants hinted that personality and character traits such as being caring, intelligent and responsible were considered far more important than mannerisms, appearance and sexual orientation. Yet the parents still felt judged and were concerned for their son's safety and wellbeing. They implied that their sons' "homosexual lifestyle" might reflect "cultural dissonance" [27], due to a "mismatch" with portrayals and conceptualisations of masculinities as depicted within the broader public sphere. Masculinity was mainly understood, perceived, judged and evaluated in terms of external sources coming from friends, neighbours, family members and society at large. The parents' notions of appropriate versus inadequate expressions of masculinity were measured against social dictates which the parents felt, assumed power over them and subjected them to mechanisms of approval seeking. As we argued in another article, social influences exert considerable power over parents of LGBTQI children to the extent that these determine how they feel, think and act in relation to their child's homosexuality [13]. This counts also for 
their perceptions on masculinities and the moral codes attached to them. A study on reference group dependence in relation to perceptions on masculinity shows that masculinity might be constructed around the exclusion of others and that men who follow traditional masculinity norms tend to be more dependent on these groups [28].

Changes in situatedness pertaining to before and after coming out have influenced the parents' perspectives on homosexuality and on notions of masculinity. New knowledge was gained and reflected upon. This ongoing process requires tackling new situations that arise. The method of secrecy employed by some of the parents to avoid talking about their son's homosexuality could have hindered the positive effects of coming out and restricted family bonding. Lack of communication and discussion within parents' networks as indicative of the findings might reinforce and reproduce the silences and invisibilities that surround homosexual masculinities. This could indicate the absence of a language for parents, with which to speak about masculinities which do not comply with heteronormative norms. Opening up often necessitates a certain degree of vulnerability and requires understanding, empathy, trust and safety. Self-disclosure is made more difficult for men since they have been socialized to hide their feelings in order to appear self-sufficient [6]. Perceived fear of stigmatization perpetrated by extended family members proved to be an obstacle for support seeking.

The study has implications for the understanding of masculinities. It contends that the qualities that "make a man" revolving around physical appearance, body image, dominance, control, violence and aggression could adversely affect relationships. The findings suggest that parents conceptualizations' of masculinity could construct barriers in their relationship with their gay child. The fathers and mothers of the study expressed care and affection towards their sons and this had a great impact on the family's stability, their own wellbeing and that of their sons. Coming out might have compelled the fathers to question their own masculinity and how to do "fathering" with their gay son. The fathers approached coming out situations with caution and concern and were able to express caring emotions, which are stereotypically associated with women. The mothers also disputed entrenched binaries of hetero-homo sexuality. The parents were able to come out of their own closets by resisting heterosexist control in varying degrees in order to reach out to their sons. This required them to demystify the presumed "taken-for-grantedness" of "normal" masculinity. In general coming out has led them to experience personal growth by embarking on a process to acknowledge their son's masculinity, marked by a degree of self-acknowledgment and self-acceptance as parents of gay sons. This required courage to open themselves up to intimate, heartfelt conversations. We argue that when parents place the love for their children as their priority, that love serves whole communities and works to destigmatize LGBTQI persons and weaken social structures that promote homophobia. 


\section{References}

[1] Huang, S. (2004) Male Studies Need to Be Included in Textbook and Gender Study Syllabus. Journal of Women and Gender Studies, 17, 116-123.

[2] Connell, R.W. (2000) The Men and the Boys. University of California Press, Berkeley.

[3] Butler, J. (1990) Gender Trouble: Feminism and the Subversion of Identity. Routledge, New York, 33.

[4] Tillmann, L.M. (2010) Coming out and Going Home: A Family Ethnography. Qualitative Inquiry, 16, 116-129. https://doi.org/10.1177/1077800409350697

[5] Levant, R.F., Smalley, K.B., Aupont, M., Tanner House, A., Richmond, K. and Noronha, D. (2007) Initial Validation of the Male Role Norms Inventory-Revised (MRNI-R). The Journal of Men's Studies, 15, 83-110 https://doi.org/10.3149/jms.1501.83

[6] Pollack, W.S. (2006) The "War" for Boys: Hearing "Real Boy's" Voices, Healing Their Pain. Professional Psychology: Research and Practice, 37, 190-195. https://doi.org/10.1037/0735-7028.37.2.190

[7] Wade, J.C. and Donis, E. (2007) Masculinity Ideology, Male Identity, and Romantic Relationship Quality among Heterosexual and Gay Men. Sex Roles, 57, 775-786. https://doi.org/10.1007/s11199-007-9303-4

[8] Wade, J.C. and Coughlin, P. (2012) Male Reference Group Identity Dependence, Masculinity Ideology, and Relationship Satisfaction in Men's Heterosexual Relationships. Psychology of Men and Masculinity, 13, 325-339. https://doi.org/10.1037/a0026278

[9] Burn, S.M. and Ward, Z.A. (2005) Men's Conformity to Traditional Masculinity and Relationship Satisfaction. Psychology of Men and Masculinity, 6, 254-263. https://doi.org/10.1037/1524-9220.6.4.254

[10] Levant, R.F. (1996) The New Psychology of Men. Professional Psychology: Research and Practice, 27, 259-265. https://doi.org/10.1037/0735-7028.27.3.259

[11] Cassar, J. (2009) Being a Lesbian Is No Sin: Religion, Sexuality and Education in the Lives of Female Students. Mediterranean Journal of Educational Studies, 14, 45-67.

[12] Cassar, J. (2015) Sex and Secrecies: An Exploration of Students' Conceptualizations of Heteronormativity. Journal of LGBT Youth, 12, 419-435. https://doi.org/10.1080/19361653.2015.1077769

[13] Cassar, J. and Grima Sultana, M. (2016) Sex Is a Minor Thing: Parents of Gay Sons Negotiating the Social Influences of Coming Out. Sexuality and Culture, 20, 9871002.

[14] House of Representatives (2015) Act XI of 2015: Affirmation of Sexual Orientation, Gender Identity, and Gender Expression Act. Malta.

http://www.justiceservices.gov.mt/DownloadDocument.aspx?app=lomanditemid=1 2610andl=1

[15] House of Representatives (2014) Act IX of 2014-Civil Unions. House of Representatives, Malta.

http://justiceservices.gov.mt/DownloadDocument.aspx?app=lpanditemid=26024an $\underline{\mathrm{dl}=1}$

[16] ILGA Europe (International Lesbian, Gay, Bisexual, Trans and Intersex Association) (2016) Annual Review of the Human Rights Situation of Lesbian, Gay, Bisexual, Trans and Intersex People in Europe 2016. ILGA Europe, Brussels, 16. 
http://www.ilga-europe.org/sites/default/files/Attachments/annual_review_2016-for =web.pdf

[17] House of Representatives (2017) ACT No. XXIII of 2017. Act No. Marriage Act and Other Laws (Amendment) of 2017.

http://justiceservices.gov.mt/DownloadDocument.aspx?app=lp\&itemid=28609\&l=1

[18] European Commission (2015) Discrimination in the EU in 2015: Eurobarometer 83.4 Results for Malta. 3.

http://ec.europa.eu/COMMFrontOce/PublicOpinion/index.cfm/Survey/getSurveyD etail/search/discrimination/surveyKy/2077

[19] Martino, W. (2000) Policing Masculinities: Investigating the Role of Homophobia and Heteronormativity in the Lives of Adolescent School Boys. Journal of Men's Studies, 8, 213-236. https://doi.org/10.3149/jms.0802.213

[20] Plummer, D. (1999) One of the Boys: Masculinity, Homophobia, and Modern Manhood. Haworth Press, New York.

[21] Malta Gay Rights Movements (2003) Sexual Orientation Discrimination in MaltaA Report on Discrimination, Harassment and Violence against Malta's Gay, Lesbian and Bisexual Community, 8 .

http://www.maltagayrights.org/cms/pdfs/sexual-orientation-discrimination-in-malt a.pdf

[22] Goldfried, M. and Goldfried, A. (2001) The Importance of Parental Support in the Lives of Gay, Lesbian, and Bisexual Individuals. Journal of Clinical Psychology, 57, 681-693. https://doi.org/10.1002/jclp.1037

[23] Braun, V. and Clarke, V. (2006) Using Thematic Analysis in Psychology. Qualitative Research in Psychology, 3, 77-101, 6.

[24] Broad, K.L. (2002) Social Movement Selves. Sociological Perspectives, 45, 317-336. https://doi.org/10.1525/sop.2002.45.3.317

[25] Bradford, S. and Clark, M. (2011) Stigma Narratives: LGBT Transitions and Identities in Malta. International Journal of Adolescence and Youth, 16, 179-200. https://doi.org/10.1080/02673843.2011.9748054

[26] Katz-Wise, S.L. and Hyde, J.S. (2012) Victimization Experiences of Lesbian, Gay, and Bisexual Individuals: A Meta-Analysis. Journal of Sex Research, 49, 142-167. https://doi.org/10.1080/00224499.2011.637247

[27] Nayak, A. and Kehily, M.J. (2008) Gender, Youth and Culture: Young Masculinities and Femininities. Palgrave MacMillan, Hampshire, 50. https://doi.org/10.1007/978-1-137-12214-8

[28] Wade, J.C. and Brittan-Powell, C.S. (2001) Men's Attitudes toward Race and Gender Equity: The Importance of Masculinity Ideology, Gender Related Traits, and Reference Group Identity Dependence. Psychology of Men and Masculinity, 2, 42-50. https://doi.org/10.1037/1524-9220.2.1.42 
Submit or recommend next manuscript to SCIRP and we will provide best service for you:

Accepting pre-submission inquiries through Email, Facebook, LinkedIn, Twitter, etc. A wide selection of journals (inclusive of 9 subjects, more than 200 journals)

Providing 24-hour high-quality service

User-friendly online submission system

Fair and swift peer-review system

Efficient typesetting and proofreading procedure

Display of the result of downloads and visits, as well as the number of cited articles Maximum dissemination of your research work

Submit your manuscript at: http://papersubmission.scirp.org/

Or contact jss@scirp.org 